\title{
The kingdom of God: Utopian or existential?
}

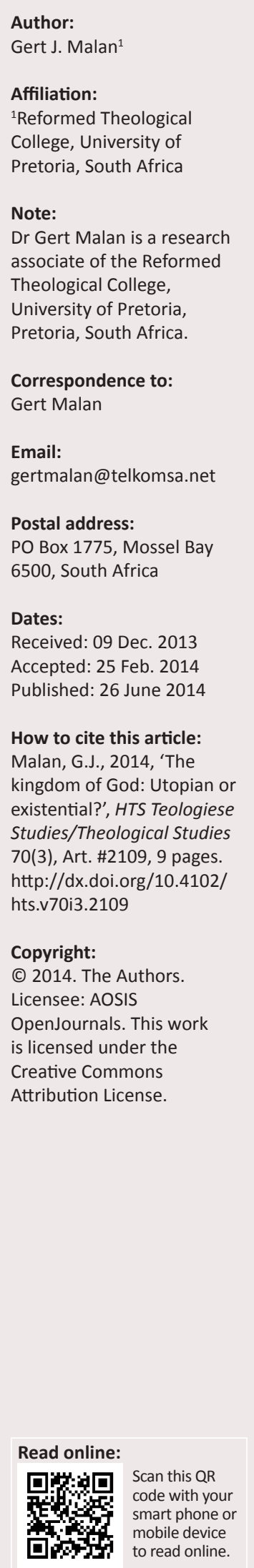

The kingdom of God was a central theme in Jesus' vision. Was it meant to be understood as utopian as Mary Ann Beavis views it, or existential? In 1st century CE Palestine, kingdom of God was a political term meaning theocracy suggesting God's patronage. Jesus used the term metaphorically to construct a new symbolic universe to legitimate a radical new way of living with God in opposition to the temple ideology of exclusivist covenantal nomism. The analogies of father and king served as the root metaphors for this symbolic universe. They are existential root metaphors underpinning the contextual symbolic universe of God's patronage in reaction to the collapse of the patronage system which left peasants destitute. Jesus' paradoxical use of the metaphor kingdom of God had a therapeutic value and gave the concept new meaning. The initial motivation for proclaiming God's patronage originated in Jesus' primary identity formation by Mary as single parent and was reinforced in his secondary identity formation by John the Baptist. From these results can be concluded that kingdom of God was not meant to be understood as utopian, but existential. In order to clarify the meaning of kingdom of God and God's patronage for the 21st century, demythologisation and deconstruction can be helpful especially by highlighting the existential meaning of the kingdom of God.

\section{Utopia}

The word utopia was coined in the 16th century by Sir Thomas More in his book about an ideal, communal society living on a remote island called Utopia. Utopia is a wordplay on two Greek words: ou-topos [no place, implying unattainable] and eu-topos [good place as in ideal society] (Miller in More 2001:ix). Utopian ideals, as reflected in ancient idealistic movements and literature, reveal that the concept is much older. In her book Jesus $\mathcal{E}$ utopia, Mary Ann Beavis (2006) brings together Jesus' teaching on the kingdom of God and the ancient utopian literature and movements. To Beavis (2006:2), Jesus' language about the kingdom of God is patently utopian, suggesting a realm ruled by God, thus an ideal commonwealth where perfect justice and social harmony exists. However, the implication that should have been drawn from the double meaning of utopia is that the kingdom of God viewed as utopian is both ideal and unattainable. Life in the kingdom of God would be existence within tension between reality as the not yet attained ideal, and the ideal itself. Viewed in this way, realising the utopia in any space and time is problematic. Both time (linearity) and space must be overcome. The irony of the double meaning of utopia seems to be that there is no place such as the ideal place, only the tension whilst striving for it.

This article investigates whether Jesus' concept of the kingdom of God was meant to be understood as utopian, specifically in the sense that Beavis understands utopia. This article delimits the scope to Beavis's approach and does not concern itself with other authors' views on utopia. Hopefully the article can in future be supplemented by a further comparison of the kingdom of God and other utopian ideas, such as Mannheim's work on utopia and ideology. Insights from literary, historical and social scientific approaches are used to test Beavis's stance. But firstly, we should look at kingdom of God as metaphor.

\section{Kingdom of God as metaphor with new meaning}

Since the Kantian epistemological revolution the term analogy gained importance. Immanuel Kant argued convincingly that the metaphysical world as such cannot be known, thus the transcendental can only be known and described by using analogy or symbols (Hopper 1987:54). All language about God is therefore metaphorical language. Bultmann (1967:23) described mythological language (a kind of analogical or metaphorical language) as speaking of the 'Unweltliche weltlich, von den Göttern menschlich'. Metaphors use analogy to describe one thing in terms of another and as such provide the needed symbolic language to speak about the metaphysical (Malan 1998:74-75). Whilst symbols tend to imply independent ontological entities floating about in an ideal Platonic realm, metaphors by contrast are related to the actual world of people in specific cultures. As Buckley (1992:200) suggests, '[b]y their very nature metaphors depend on specific, context-bound notions for their meaning.' 
The concept of root metaphors is primarily drawn from the work of philosopher Paul Ricoeur and theologians Don Browning and Sally McFague on language, religion and culture (Bulkley 1992:198). Root metaphors describe the most basic assumptions about reality or experience (McFague 1983:201, n. 27). The most fundamental questions about human existence are better explained with the help of root metaphors. They are special metaphors that use tangible, concrete images from human experience to help us answer profound, intangible questions like: What are good and evil? What makes for a meaningful and happy life? (Bulkley 1992:198). As such, root metaphors are used to convey core values of a society. Root metaphors and the core values they express legitimise the institutional order and are the basis for individuals' identity forming (Malan 1998:76). As early as 1942, Pepper formulated his root metaphor theory in the field of philosophy. What Berger and Luckmann (1975:110-146) call a symbolic universe Pepper (in Lyddon 1989) calls a worldview or world hypothesis. Root metaphor theory explains which kind of root metaphor underpins which kind of world hypothesis. Pepper identifies four world hypotheses namely formalist, mechanistic, contextual and organismic. Each world hypothesis is associated with a style of thinking: analytical thinking for the formalist view; causal thinking for the mechanistic approach; existential appropriation in the moment of a historical event as it is happening is the style of thinking for the contextual viewpoint; and thinking that focuses on movement to organic wholes is the style of the organismic worldview (Pepper in Lyddon 1989:442-443).

A symbolic universe, as sociology of knowledge views it, is a symbolic (metaphorical or analogical) world of ideas which functions as a frame of reference (Malan 1998:86-87). It legitimates and explains life in a specific social world (society). It gives meaning to the lives and roles of members of a society, supports identity forming and protects a society by legitimising certain behaviour, whilst opposing actions and ideas endangering the values and coherence of a society. Symbolic universes specifically explain the meaning of complex so-called marginal experiences such as illness, disasters, death and the afterlife. By explaining these events symbolic universes protect societies from anxiety which usually accompany these occurrences (see Berger \& Luckmann [1975:110-127] and the more detailed discussion below).

Jesus' use of the metaphor kingdom of God often demanded existential decisions from people, suggesting it to be an existential style root metaphor underpinning a contextual kind of world hypothesis (symbolic universe). Kingdom of God expresses the view that God rules the world. In 1st century CE Mediterranean societies it referred to God acting as a patron (Malina 2001:34). From this we can conclude that the root metaphor kingdom of God constructs and nuances a symbolic universe of God's patronage. This world hypothesis would demand existential appropriation in the present moment by followers of Jesus. It would legitimise their society and offer them a meaningful existence.
A contextual symbolic universe is constructed around and supported by more tangible and concrete root metaphors which are also contextual. As a result, the meaning of any event or concept is intimately tied to specific contexts which are constantly in flux (Lyddon 1989:443). In this sense God's patronage is supported and explained by the tangible contextual root metaphors such as king to his subjects and father to his children. With this symbolic universe and its root metaphors Jesus conveyed the core values he intended for his followers. These root metaphors also demand existential choices, like the symbolic universe they support. The meanings of these metaphors, their core values and the decisions they demand are to be explained from their nuances in 1st century CE Mediterranean context, namely the prevalent views on the patronage of kings and fathers and, as such explaining the nuances of God's patronage (symbolic universe).

Pepper's (in Lyddon 1989) root metaphor theory helps us to understand the style of thought underpinning a specific kind of world hypothesis. He does not focus on root metaphors as concrete, tangible analogies but more like a Platonic idea, which is not very useful in the appropriation of the root metaphors within their symbolic universe. Nevertheless, his observation that root metaphors construct the interpretations of reality (worldviews or symbolic universes) is important.

Marcus Borg (1994:80-81) noted that Jesus used the language of paradox and reversal when he spoke of the kingdom of God, thus shattering conventional wisdom, consequently causing chaos. Crossan (1979:23) concurs with Borg when he describes the paradoxical way in which language works within parables, giving rise to new metaphors deviating from and challenging the status quo. Stephen Lankton (quoted in Davies 1995:132) describes the therapeutic value of paradox as promoting thoughts and solutions. This in turn facilitates change in clients by overloading their conscious mind, allowing them novel experiences. The following confusion frees the subconscious to apply something previously not considered as a solution to a problem (Davies 1995:133). The paradoxical metaphor kingdom of God is purposefully left undefined in order to allow followers to fill it with their own meaning. In this way the subconscious opens up new possibilities by reframing. Reframing can be defined as changing the conceptual and/or the emotional meaning attributed to a situation (Davies 1995:144). In this way Jesus gave the concept kingdom of God a new conceptual and emotional meaning, which had a therapeutic value for his followers by giving their lives new meaning and hope.

\section{The function of metaphors in the social and symbolic universes}

It is important to reiterate that all language about God is metaphorical (analogical, mythological or symbolical). We speak about God in human terms, trying to convey our insights and beliefs in a way others can comprehend. This results in objectifying. As Bultmann (1965:146) put it: myth objectifies the transcendental (das Jenseitige) to the immanent 
(das Diesseitige). This objectifying quality of metaphors (analogies, myths or symbols) is also an important quality of symbolic universes that legitimise social universes. Symbolic universes originate from social universes and become all encompassing and objectifying frames of reference (Malan 1998:86-87). Consequently, what specific meaning a symbolic universe projects (objectifies) about the social reality, relates to people's ideas about the meaning of their lives within a specific social reality and can be deduced from the root metaphors used to convey the core values of that society.

Social realities are legitimised by symbolic universes. Symbolic universes refer to a higher order that gives meaning and structure to social life, and especially to the borderline (marginal) experiences like suffering, loss and death. The language of symbolic universes is analogical language like metaphors, myths and symbols. They explain how the higher order legitimates every relationship in the social world of every day. A social universe is the sphere where people interact face to face according to certain accepted conventions which are legitimised by a symbolic universe. Different social groups have different symbolic universes which can overlap or completely oppose each other. Crisis ensues when a symbolic universe disintegrates leading to social chaos, or when in spite of an intact symbolic universe, the legitimised social conventions are neglected or negated. Such disregard renders the symbolic universe useless and creates an existential crisis of life not making sense. Such a crisis calls for universe maintenance or a new symbolic universe, a new way of making sense of life and relationships (see Berger \& Luckmann 1975:110-127).

It will be argued below that it is probably into such an existential void that Jesus stepped speaking in the metaphor of the kingdom of God, filling the metaphor with new meaning. He is offering a new symbolic universe of God's patronage with new core values and a new way of life in 1st century Palestine. This is not to be understood as universe maintenance. Jesus did not intend to restore the Judean religion but to oppose and radically alter it. It can be compared to a revolutionary paradigm shift, thinking of God and living with God in a way not previously thought of. This is underscored when we view the kingdom of God as a sociopolitical and religious term. Only then can we better identify the core values important to Jesus' symbolic universe. First we have to investigate the influence of symbolic universes on identity formation.

\section{Symbolic universes and identity formation}

When trying to understand identity from a social perspective, it is important to recognise the dialectic between the social world with its legitimising symbolic universe as a human construct and the effect of this construct on human life. The human product continually acts back upon its producer. Every individual biography is an episode within the history of society (and under its sacred canopy), which both precedes and survives it. It is within society and as a result of social processes that the individual becomes a person, that an identity is attained and held and that the various projects that constitute a life are carried out:

The fundamental dialectic process of society consists of three moments or steps: externalization, objectivation and internalization. Externalization is the ongoing outpouring of human being into the world. Objectivation is the attainment by the products of this activity of a reality that confronts its original producers as a facticity external to and other than themselves. Internalization is the reappropriation by [people] of this same reality, transforming it once again from structures of [the] objective world into structures of the subjective consciousness. (Berger 1973:13-14)

It is through externalisation that society is a human product. It is through objectivation that society becomes a reality sui generis. It is through internalisation that people are products of society (Berger 1973:13-14).

Identity is a phenomenon that emerges from the dialectic between the individual and society with its social and symbolic universes. It is a key element of subjective reality and the product of social processes. Once crystallised, it is maintained, modified or even reshaped by social relations. These social processes that form and maintain identities are determined by the social structure and symbolic superstructure (see Berger \& Luckmann 1975:194-195).

Identity formation is closely related to primary socialisation as a child, and is more important than secondary socialisation of later life. Primary socialisation involves much more than cognitive learning. It takes place under circumstances that are highly charged emotionally. The child identifies with significant others in a variety of emotional ways. Whatever they may be internalisation only occurs as identification occurs. Children take on the roles of significant others and make them their own, thus becoming able to identify with themselves or acquiring subjectively coherent and plausible identities. Important to note: There is no choice of significant others in primary socialisation. Since children have no choice in the selection of significant others, identification with them is quasi-automatic (Berger \& Luckmann 1975:151-152). The implication is that children simply take over the social universe of significant others as well as the symbolic universe which legitimises it.

Secondary socialisation is undertaken by agents of society like teachers and not significant others. Secondary socialisation is the internalisation of institutional or institution-based subworlds determined by the division of labour and knowledge. These subworlds are generally partial realities in contrast to the 'base-world' acquired in primary socialisation. In primary socialisation children accept their parent's view of the world as 'the world'. Problems arise in secondary socialisation when they learn other and different versions of the world (Berger \& Luckmann 1975:157-166). This means that both the social and the legitimising symbolic universes are questioned, for instance in adolescence. 
To conclude: Symbolic universes play a very important role in identity formation. When someone is socialised within a certain society, it is not only their way of life that is learnt but also their understanding of the meaning of life and the role the individual has to play. In other words, they need to understand the symbolic universe with its core values that legitimises the social world of relationships, roles and way of life of the group. A high percentage of internalisation (it is never complete) means a large part of such a person's identity is conformed to the norms of society. When internalisation is not as successful, a person's identity is less conformed to that of society. The way of life and the symbolic universe legitimising it will be questioned.

An important question to ask with reference to identity forming is which core values were conveyed by the symbolic universe of God's patronage through its root metaphors of king and father. To answer this question we have to understand the context in which the metaphors were used and the meaning they would have had for people living in 1st century Palestine. Referring to the paradoxical (therapeutic) use of the metaphor kingdom of God, it is important to ask to what problems Jesus' new understanding of the kingdom of God was seen as a solution. Investigating the socio-political sphere of 1st century Palestine will enlighten us.

\section{Kingdom of God as metaphor from the socio-political religious sphere}

Malina's viewpoint is that the outcome of Jesus' proclaiming the kingdom of God shows that the kingdom was political and not metaphorical (Malina 2001:1). I concur with Malina's view that the term kingdom of God is a political term, but differ from him in the sense that I recognise that kingdom of God is a metaphor designating the kind of change Jesus hoped to effect. An important question to ask is in what kind of 1st century Mediterranean social context would the proclamation of the kingdom of God make sense (Malina 2001:1)?

The first part of the answer would be the Roman imperial system of power and extortion of the peasants by the elite, which, in its all-embracing societal control and rule by fear can in some instances be compared to the functioning of powerful crime syndicates like the Sicilian Mafia. Its control was based on fear as well as a broad consensus provided by oaths of loyalty towards patron elites. Farming was not yet developed past subsistence, meaning there was no surplus production. This was true of all parts of the subsistence economy, making it almost impossible to survive without the patronage system of reciprocity between unequal parties living in close proximity (Malina 2001:29-31).

The second part of the answer pertains to Palestine specifically. Unlike in some parts of the Roman Empire where land was a sacred, inalienable domestic holding, land in Palestine was saleable. The gradual disappearance of smallholdings and the increased growth of large holdings are evidence of Israelite elites being remiss in their obligations towards their local clients. Clients (peasants) had to sell their land in order to survive. Instead of mediating with the Romans for a status quo situation, Israelite elites chose to use their own power as well as the Roman presence to constrain the local peasantry beyond endurance (Malina 2001:33-34).

It is important to remember that 1st century CE Israel was a temple state (Van Aarde 2001:128). It was the control centre for God's dealings with the world (Malina 2003:416). In this sense it can be viewed as a kind of theocracy, although hierocracy seems a more fitting term. In a cultic sense, the temple in Jerusalem was viewed as the navel of the earth, connecting this world to the other world, resulting in the temple elite being mediators between the two worlds (Borg 1984:28). Politically, the Sadducees ruled over the temple state since the Maccabean War in the 2nd century CE. Since then high priests have been appointed from their family ranks. The result was that regulation of priestly duties, including the collection of offerings, was compromised by family interests (Van Aarde 2001:128).

Offerings formed the basis of a taxation system that was supposed to be grounded in the economic values of reciprocity and redistribution. The peasants supplied the aristocratic temple elite with their produce (Van Aarde 2001:128). In total, peasants had to contribute $20 \%$ of their produce to the temple. Add to this the Roman taxation and the total could possibly amount to as much as 35\% (Borg 1984:84-85). The temple functioned as centre for the redistributive political economy:

With large treasuries and storehouses for material of all sorts, the temple functioned somewhat like a national bank and storage depot. It became the repository of large quantities of money and goods extracted from the surplus product of the peasant economy. Because most of the temple precincts were inaccessible to all but a handful of priests and closely guarded against intrusion they offered a high level of security for the economic resources for the political and religious elite. (Malina 2003:417)

As their patrons, the elite had to reciprocate by looking after the needy. As the hierarchical ladder became too long as a result of additional taxes that had to be supplied to rulers on higher rungs of the ladder, peasants towards the bottom had to supply more surpluses on smaller bits of land. At the same time, less was passed down by their supposed patrons. In a way, the taxes more than doubled. Extended families in the peasant communities started to break up and poverty increased (Van Aarde 2001:128).

The policies of the temple elite were determined by the purity ideology that marked the conventions of the entire Israelite society as exclusivist and hierarchical. It circumscribed familial, political, economic and religious life. The population was stratified in 14 categories from holy to less holy to impure. Only the first four categories of holiness or purity could enter the temple. In this way the majority of the population was excluded from the temple and thus from God's presence (Van Aarde 2001:128-133). Cromhout 
(2007:114-115) called this policy Judean covenantal nomism. Even the design of the temple supported the ideology of ethnocentricity. In concentric circles from the inner holy of holies to the Court of the Gentiles, the temple precincts replicated an ethnocentric view of the cosmos. The temple in this way functioned as a map for social relations for Israelite society (Malina 2003:416-417).

Jesus' proclamation made sense in this context of disenfranchised peasantry disillusioned with the failing patronage system, which came down to veritable betrayal and disloyalty by the elites towards the peasantry. Add to this the Roman imperial rule by force and fear. The message of God's divine patronage made sense to the impoverished powerless peasantry and gave them hope (see Malina 2001:34-35). In this context kingdom of God as a socio-political term makes sense.

\section{God's patronage as symbolic universe and its root metaphors}

Considering the symbolic universe of God's patronage as constructed around the root metaphors of king and father, it is important to acknowledge that the concept of patronage denoting the symbolic universe is also a metaphor. This is supported by Cromhout's (2007:114-115) work on Judean ethnicity. Covenantal nomism is the symbolic universe describing 1st century CE Judean ethnicity and religion. Covenantal nomism is also a metaphor: The relationship between Judeans and God can be compared to a covenant between God and Judeans, with stipulations which function as laws that Judeans must obey. The symbolic universe of God's patronage carries within its metaphor the essence of what is legitimated in the social world. It suggests legitimation of the rule of God as patron in the social world. In order to understand how it could function in practise, we should consider the metaphor as well as the root metaphors around which it is constructed.

Patronage is already embedded within the root metaphors kingdom of God and the father of a family, as kings and fathers were viewed as patrons to their subjects or families. Patronclient systems are socially fixed relations of generalised reciprocity between social unequals. The lower status clients in need have their needs met by higher-status, well-situated patrons. Being granted such favour, the clients implicitly promise to reciprocate whenever and however the patron determines. By granting the favour, the patron implicitly promises to be open for further requests at unspecified later times. Such open-ended relations of generalised reciprocity are typical of the relation between the head of the family and his dependants: wife, children and slaves. By entering a patron-client arrangement, clients relate to their patrons as superiors and more powerful kinsmen, whilst the patrons see their clients as their dependants (Malina 2003:388).

Brokers mediate between clients below and patrons above. First order resources such as land, jobs, goods, funds and power are all controlled by patrons. Second order resources like strategic contact with or access to patrons are controlled by brokers who mediate the goods and services a patron has to offer. In the New Testament the language of grace is the language of patronage. God is the ultimate patron whose resources are graciously given, mediated by his broker Jesus. By proclaiming that the kingdom of God has come near (Mk 1:15) Jesus is in effect announcing God's patronage and sets himself up as broker (Malina 2003:389-390).

The root metaphor of father in relation to family opens another nuance of God's patronage. The nuance this root metaphor brings to the idea of God's patronage is very important: 'The role that the God of Israel would play on behalf of his people, was not that of a monarch, but that of Father' (Malina 2001:34). It is the dominant metaphor from patronage which Jesus used to describe the new relation the faithful could have with God as their father. What would a 1st century CE Mediterranean society expect from such a relationship? They would expect it to function like their families do.

In the 1st century CE Roman world as well as in the Judean religious world, men were by nature thought of as superior to women. Especially Jewish men thought themselves to be the most eminent of God's creatures and they, not women, had to perpetuate mankind. Men had to perform all religious duties like sacrificing in the temple and visiting the synagogue. The father was the major figure in the family. In the Roman world and law the father, as pater familias, had power over his family throughout his life, even after the children had married and set up their own households. Children could not possess or sell land, or make a will without their father's consent. The father's power over his family (patria potestas) meant he had the right to decide whether he accepted a child as his or not. He could reject a child, and as such a baby was often left on one of the dumps outside the town or city. A father had the right to sell his children as slaves, or have them put to death if they disobeyed him. Although the Jewish world did not have the same kind of laws regarding a father and his children, the father was the undisputed ruler and his children owed him absolute obedience. A father's duty was to supply his family with food and clothing; he had to represent them in public, in the cultic place, and defend their good name and had to help to educate his children. A Jewish father was expected to teach his son the laws of the Lord and take his sons with him to the public religious meetings after their 12th year (Malina, Joubert \& Van der Watt 1996:6). It is clear that the relation between a 1st century CE Jewish father and his children (and his wife and slaves) was analogous to that of a patron-client. This nuance is implied with the symbolic universe of God's patronage and underpinned by the root metaphor of a father to his family. Jesus thus proclaimed God's patronage as the patronage of a caring father to the faithful, who as his children and dependants honour and obey him. As the proclaimer of God's patronage, Jesus set himself up as broker of this radical new surrogate family which would function in opposition to the failing patronage system of the Israelite temple-state. Serving as root metaphor next to the kingdom of God, they give nuance to each other and become synonymous. 
Viewed in this way, the core values implicit in the kingdom of God would be reliable reciprocity brokered by Jesus. In honourshame societies of the 1st century CE Mediterranean world, being reliable would be honourable, whilst unreliability would be viewed as shameful.

The kingdom of God given nuance as the household or family of God would function as a fictive or surrogate family and would serve the same functions as a family of biological origin (Malina 2003:414). They would transcend the normal categories of birth, social status, education, wealth and power. As a place of refuge, especially for those detached from their families of origin, the members became like brothers and sisters to each other (Malina 2003:414). In this regard they were expected to be reliable in their care for each other. The core value implicit would be love, understood as loyalty to the group (Malina 2003:380). This meant that members of the group had to take responsibility for each other and for the group. Being reliable in this reciprocal caring was crucial.

Van Aarde (2001) correctly summarises:

The kingdom of God is not comparable to earthly kingdoms where humaneness vanishes behind various symbols of power and hierarchy. Instead it is comparable to a household where distorted relationships are healed by means of the ethos of compassion (referring to Borg 1994:46-68) and God's unmediated presence (see also Crossan:1992:225-410). (p. 43)

This summary already suggests deconstruction of the failing patronage of the temple elite on the part of Jesus, to which we will return later.

\section{Jesus' identity forming as the origin of God's patronage as symbolic universe}

Primary identity formation is the most important kind of identity formation. We must reiterate that there is no choice in the selection of the significant others with whom the child identifies in a quasi-automatic way (Berger \& Luckmann 1975:151-152). They simply take over the social universe of significant others as well as the symbolic universe which legitimises it. Andries van Aarde (2001:119-134) has suggested that viewing Jesus as an ideal-type of a fatherless figure in the 1st century CE helps us explain coherently and systematically the individual facets of his life. Thus it was his mother who was responsible for his primary identity formation. From Van Aarde's fatherless Jesus perspective, I draw the conclusion that Jesus took over the single parent Mary's (despite his later strained relationship with her) impression of her social world and its symbolic universe as she viewed it, or possibly even her ideas about how her social world could have been changed by a radically new symbolic universe. As storytellers, mothers imparted tradition and wisdom, and formed children's behaviour. Van Aarde (Van Aarde 2001:124) even refers to typical female behaviour to be found in the list of authentic deeds of the historical Jesus. From this can be concluded that Mary could have played a major role in Jesus' eventual vision and proclamation of the kingdom of God, of calling God his father and teaching others to do so.

Regarding secondary identity formation, Van Aarde (2001:125) explains Jesus calling God his father as a fantasy produced by a fatherless boy going through the Oedipal complex as important in his identity formation and eventual estrangement from his village, leading up to his immersion to cleanse him from the systemic sin of fatherlessness (Van Aarde 2001:42). Probably John the Baptist played an initial role as his mentor and contributed to his secondary identity formation. It seems Jesus stayed with John up to John's arrest. He then took up his role as prophet (Malina 2003:148), also calling people to repent (see Mk 1:14-15). After leaving the Baptist's circle, his road deviated from the Baptist's in order to focus on the social outcasts, especially women and children (Van Aarde 2001:46).

In conclusion, Jesus' idea of being a child of God and envisioning the concept kingdom of God, suggest that either Jesus' internalisation of his primary socialisation by Mary was not very successful or that she taught him to question the prevalent social order according to another possible symbolic universe. Both explain his radical questioning of the covenantal nomism, suggesting a radical new way of life, legitimised by his own understanding of the kingdom of God. His secondary identity formation seems to have confirmed and strengthened this view.

\section{Was the kingdom of God meant to be utopian?}

Beavis (2006:86) has shown that in most cases, Jewish hopes for a future utopian age hark back to idealised eras in the sacred history which were interpreted as models for divinely sanctioned rule to be implemented perfectly in the future (e.g. the divinely promised land overflowing with milk and honey; the powerful tribal federation under the leader Joshua; the golden age of David and Solomon; the ethnically uniform hierocracy of Ezra-Nehemiah).

Beavis's (2006) reasoning does not include understanding God's patronage as new symbolic universe constructed around the existential root metaphors kingdom of God and God as father to a family. She does not identify the idealised models from the past as metaphors creating symbolic universes which were meant to legitimise new social orders. In this sense she fails to see the irony of these models and the hopes for future utopias they were meant to have legitimated: They were idealistic portrayals that did not exist in that way (Beavis 2006:87-89). These good places were no places! They did not come into being. Jesus' vision of the kingdom of God was not designed to be understood as utopian but to existentially realise a new social order and way of life wherever followers of Jesus lived accordingly and transformed that place to a good place to be. 
In this sense Philo comes closer to understanding kingdom as a root metaphor supporting wisdom's symbolic universe of God's order to which people should conform. He refers to the basileia of wisdom as wisdom's control over the wise man's affairs (in Beavis 2006:89). Ironically Beavis (quoting Burton Mack) shows that kingdom of God originated in the wisdom tradition (wisdom is where creation of symbolic universes starts) and not in the apocalyptic tradition but fails to recognise it as a root metaphor explaining God's patronage (Beavis 2006:89). Precisely this is the reason for her agreement with Doron Mendels who considers Jesus' proclaiming the kingdom of God as non-political but transcendental, because Jesus did not hark back to utopian eras in Israelite history, and remained as vague as possible with nebulousness about the kingdom and with no concrete plans like Hellenistic utopians (Beavis 2006:94). The flaw in their reasoning is that the existential root metaphor kingdom of God was and is political because it was meant to legitimate a certain social order and way of life in direct opposition to the social world as dictated by the Israelite temple-state and its ideology of covenantal nomism. The vagueness of the metaphor kingdom of God's symbolism transcends space and time, culture and history and keeps on legitimising the kingdom of God in other instances in space(s) and time(s). Kingdom of God was an existential concept and not a utopian ideal.

\section{Demythologising God's patronage}

A hermeneutical problem arises when God's patronage is to be applied to the 21st century Western theological tradition. The hermeneutical problem lies with the reciprocity implied in the metaphor. How does God care for the faithful? Is a sacrificium intellectus required? Is prayer the answer to all problems of the faithful? Do the responsible faithful not take their sick to the doctor or their car to the mechanic? Do the responsible faithful not work for an income and administrate their money wisely in order to care for their families?

Bultmann suggested demythologising the New Testament kerugma by means of existential interpretation. According to Bultmann (1958:1213), Jesus' notion of the kingdom of God was apocalyptic and eschatological: it would be realised by God in the near future. The nearness of the coming kingdom was to be seen in Jesus' healing signs and wonders, especially his exorcisms (Bultmann 1980:6-9). According to Bultmann, this does not mean that the kingdom of God became a reality then, but only that it was approaching. However, Jesus called people to decision in the present, thus preparing them for the coming kingdom. Eschatological concepts (such as the kingdom of God) should not be eliminated from the kerugma. One should rather seek their essential meaning (Bultmann 1958:18, also 1967:21-22). Bultmann emphasised that several aspects of New Testament soteriology do not make sense to modern people and should be demythologised by asking for the existential truth they represent. For instance, today people do not view death as punishment for sin but as the natural end to biological life. Bultmann reasons that the idea of people being punished for the sins of their forefathers is today viewed as impossible and sub-moral.
For Bultmann, such mythological talk should not be viewed as representing an objective and acceptable worldview. It represents people's specific self understanding in their world. To make it intelligible for people today, it needs to be interpreted existentially (Bultmann 1967:21). I believe this is also true of the mythological and metaphorical concept of God's patronage. It is not intelligible to Western oriented 21st century people and should be interpreted existentially. We should ask what truth is expressed by God's patronage and how it can be translated in an existential way.

As noted above, patrons of 1st century Palestine forsook their duty and left their clients in dire straits. Jesus proclaimed God's patronage with the root metaphors of kingdom of God and father of a family, suggesting that God is the only reliable patron. In practice (existentially), the followers of Jesus became a fictive family for each other, namely the children of God their Father. By caring for each other they represented and realised God's care. By caring for others they proclaimed God's care of them. Their worship and obedience to God served as honouring their patron, who cared for them. In effect they became patrons to each other. This can be described as faith in action (see Nancy's deconstruction below - 'Deconstructing God's patronage', para. 4). The reciprocity is not lost, as the faithful reciprocate the care amongst themselves. The existential (demythologised) interpretation is that people of the kingdom of God react to God's patronage by taking responsibility for themselves and others and as such represent the patronage of God.

\section{Deconstructing God's patronage}

We return to Pepper's (in Lyddon 1989) remarks on contextual root metaphors taking their meaning from the context which is continually in flux. The current postmodern people do not understand the social context in which patronage was acceptable nor can they comprehend such a system. A hermeneutical method is needed to help them in this regard. Deconstruction can help us to retain the existential appropriation of the metaphor kingdom of God. Deconstruction is the Derridean method for questioning fundamental conceptions or oppositions through close examination. Such oppositions are characteristically binary or hierarchical, involving a pair of terms in which one member is assumed to be primary or fundamental, and the other secondary or derivative, for example nature versus culture or mind versus body. Deconstruction displaces the opposition by showing that neither term is primary. The opposition is a product or construction of the text rather than something given independently of it (Merriam Webster Dictionary n.d.). As such, deconstruction has no fixed or expected endpoint or map, but is a potentially infinite process. Deconstruction in essence seeks to expose and then subvert binary oppositions in our dominant ways of thinking. In practice there are two steps: reversing dichotomies and attempting to corrupt the dichotomies themselves (Internet Encyclopaedia of Philosophy n.d.).

Before viewing God's patronage from the perspective of deconstruction it should be reiterated that Jesus himself 
deconstructed the theocracy or hierocracy of the temple elite (see 'God's patronage as symbolic universe and its root metaphors'). Those who were supposed to be mediating between this world and the other world were excluding a large part of the population by only permitting people conforming to the first four of the 14 degrees of holiness. Those who should act as patrons to the needy refuted their duty and showed themselves as unreliable. Jesus exposed and then subverted their ideology and practise by proclaiming the kingdom of God with God as patron caring equally for all, without heed to hierarchy, gender or ethnicity. He set himself up as mediator for this kingdom.

When deconstructing God's patronage, one should regard the root metaphors of king-like and father-like patronage and their core values of reliable reciprocity in caring and obeying, as well as the binary oppositions God versus people. Immediately we realise human unreliability and striving for control in contrast to God's reliability and rule. We also find it difficult to see the difference between people's caring and God's caring. In this regard the role of the mediator seems crucial, namely restoring the relationships of the unreliable people in order for them to continue to care for each other.

The root metaphors explaining existentially the meaning of God's patronage, namely a king to his subjects, but at the same time being a father to them, suggest that faith cannot be understood as merely belief. The reciprocity of the metaphors suggests a way of life as service to God as patron, who is trusted to care for the faithful. In this regard, there is a similarity with the results of post-structuralist and phenomenologist Jean-Luc Nancy (2008) in his work Disenclosure: Deconstruction of Christianity. In this work, Nancy explores the simplest constituents of a faith without objects or purposes (Bergo 2013:186). Referring to 'The Letter of James', Nancy suggested faith in action as ergon (work) in opposition to the Apostle Paul's faith as belief. Nancy seeks a faith that has nothing to do with a truth believed. He insists:

Faith resides in inadequation to itself as a content of meaning... This is not sacri-fication but veri-fication. This is also the contrary of a truth believed. This faith, above all, does not believe. It is neither credulous nor even believing in the current sense of the term. ... It is a non-belief whose faith guarantees it as un-believable, writes Nancy. (Nancy, quoted in Bergo 2013:187-188)

At this level of experimental deformalisation, it seems superfluous to ask: What does faith not believe? What is the content that is bracketed here, or undercut? For James, this faith is practical, an ergon, and for Nancy, the epistemic challenge is to keep the logoi [reason] of persuasion out of the picture:

The work of faith, the poiessis-praxis of pistis, presents itself ... under three aspects: the love of the neighbour, the discrediting of wealth, and the truthful and decided word. In each of these three aspects of work, each time what is in question is exposure to what cannot be appropriated, to what has outside [or beyond] itself ... the justice and truth of itself. (Nancy quoted in Bergo 2013:188)
Nancy's deconstruction project frames faith as a poetics of finitude - as so many ways of moving and being in a 'world' emptied of things, wherein transcendence belongs to immanence and is neither precisely temporal ('now'), nor 'spatial' (here versus there; above versus below) (Bergo 2013:187). As both time and space are overcome in this way, Nancy's suggestions are not utopian: transcendence belongs to immanence. In the same way God's patronage can be deconstructed in order to be existentially more meaningful to 21st century people. God's patronage is realised in the here and now. Faith is doing what is required. The reciprocity of the metaphor continues for the faithful within their interpersonal relationships. The unreliability of people's reciprocity will have to be countered by the imperative of them constantly forgiving each other and continually healing relationships from hierarchy and prejudice, and reconciling in order to again take care of each other.

\section{Conclusion}

The concept kingdom of God was neither utopian nor merely political. It was a powerful and existential type of root metaphor describing and establishing a radical new symbolic universe of God's patronage in opposition to the exclusivist Judean covenantal nomism. This symbolic universe was constructed around the root metaphors of God as king and father (a father-like king), proclaiming God as the only reliable patron when the local patrons failed in their duties and left peasants destitute. Jesus called God his father and viewed himself as child of God, probably as a result of primary identity forming and growing up fatherless. He proclaimed the kingdom of God and thus set himself up as its broker, in opposition to the temple elite barring the majority of people from God's presence in the temple. However, God's patronage needs to be demythologised and deconstructed to reveal its existential meaning, as patronage is unintelligible to 21st-century people. The result: Faith becomes living within a reciprocal relationship with God, brokered by Jesus. The faithful will visibly realise God's patronage by taking responsibility and caring for each other and others, and continually healing relationships through forgiveness and reconciliation.

\section{Acknowledgements Competing interests}

The author declares that he has no financial or personal relationship(s) that may have inappropriately influenced him in writing this article.

\section{References}

Beavis, M.A., 2006, Jesus \& utopia, Augsburg Fortress, Minneapolis. Berger, P.L., 1973, The social reality of religion, Penguin, Harmondsworth. Berger, P.L. \& T. Luckmann, 1975, The social construction of reality: A treatise in the sociology of knowledge, Penguin, Harmondsworth.

Bergo, B., 2013, 'The future of paradosis: Jean-Luc Nancy's dis-enclosure: Deconstruction of Christianity', Symposium 17(2), 178-203. http://dx.doi. org/10.5840/symposium201317226 
Borg, M., 1984, Jesus: A new vision. Spirit, culture, and the life of discipleship, Harper, San Francisco.

Bulkley, K., 1992, 'Dreams, spirituality and metaphors', Journal for Religion and Health 31(3), 197-206. http://dx.doi.org/10.1007/BF00986272

Bultmann, R.K., 1958, Jesus Christ and mythology, Charles Scribner, New York.

Bultmann, R.K., 1965, 'Zum Problem der Entmythologisierung', in H-W. Bartsch (Hrsg.), Kerygma und mythos: Diskussionen und stimmen zur problem der (Hrsg.), Kerygma und mythos: Diskussionen und stimmen zur problem der
entmythologisierung, Bd. 2, pp. 179-195, Herbert Raich Evangelischer Verlag, entmythologisierung,

Bultmann, R.K., 1967, 'Neues Testament und Mythologie: Das Problem der Entmythologisierung der neutestamentlichen Verkündigung', in H-W. Bartsch (Hrsg.), Kerygma und Mythos: Ein theologisches Gespräch, Bd. 1, pp. 15-48, Herbert Reich Evangelischer Verlag, Hamburg-Bergstedt.

Bultmann, R.K., 1980, Theologie des Neuen Testaments, Mohr, Tübingen.

Crossan, J.D., 1979, 'Paradox gives rise to Metaphor: Paul Ricoeur's hermeneutics and the parables of Jesus', Biblical Research 24/25, 20-37.

Crossan, J.D., 1992, The historical Jesus: The life of a Meditteranean Jewish peasant, Harper, San Francisco.

Cromhout, M., 2007, Jesus and identity: Reconstructing Judean ethnicity in Q, Clark, Cambridge.

Davies, S.L., 1995, Jesus the healer: Possession, trance and the origins of Christianity, SCM Press, London.

Hopper, J., 1987, Modern theology: Cultural revolutions and new worlds, vol. 1 Fortress, Philadelphia.
Internet Encyclopaedia of Philosophy n.d., s.v. Deconstruction, viewed 14 November 2013, from http://www.iep.utm.edu/deconst/

Lyddon, W.J., 1989, 'Root metaphor theory: A philosophical framework for counselling and psycotherapy', Journal of Counselling and Development 67, 442-448.

Malan, G.J., 1998, " $n$ Herwaarderingvan RudolfBultmannseontmitologiseringsprogram in die lig van die kennissosiologie: Die dag van die Here in 2 Petrus as voorbeeld", DD proefskrif, Departement Nuwe-Testamentiese Wetenskap, Fakulteit Teologie (Afdeling A), Universiteit van Pretoria.

Malina, B.J., 2001, The social gospel of Jesus: The kingdom of God in Mediterranean perspective, Fortress, Minneapolis.

Malina, B.J., 2003, Social scientific commentary on the synoptic gospels, Fortress, Minneapolis.

Malina, B.J., Joubert, S. \& Van der Watt, J., 1996, A time travel to the world of Jesus: A modern reflection of ancient Judea, Orion, Halfway House.

McFague, S., 1983, Metaphorical theology: Models of God in religious language, SCM Press, London.

Merriam Webster Dictionary n.d., s.v. Deconstruction, viewed 14 November 2013, from http://www.merriam-webster.com/dictionary/deconstruction

More, T., 2001, Utopia, transl. C. Miller, Yale University Press, New Haven.

Nancy, J-L., 2008, Dis-closure: The deconstruction of Christianity, transl. B. Bergo, Fordham University Press, New York.

Van Aarde, A.G., 2001, Fatherless in Galilee, Trinity, Harrisburg. 